\title{
Disaster Forecasting Approach In Indonesia: A Fuzzy Time Series - Markov Chain Model
}

\author{
${ }^{1 *}$ Rahmad Syah, ${ }^{2}$ Marischa Elveny, ${ }^{3}$ Ummul Khair
}

1,2,3Informatics, Technical High School Harapan, JL. HM. Joni no. 70 c, Medan, Indonesia;

${ }_{1 *}$ Department Computer Science dan Information Technology, Universitas Sumatera Utara, Medan, Indonesia; ${ }^{*}$ rahmadsyah45@gmail.com ,2marischaelveny@ymail.com, 3ummul.kh@gmail.com.

\begin{abstract}
The concept of Fuzzy Time Series to predict things that will happen based on the data in the past, while Markov Chain assist in estimating the changes that may occur in the future. With methods are used to predict the incidence of natural disasters in the future. From the research that has been done, it appears the change, an increase of each disaster, like a tornado reaches $3 \%$, floods reaches $16 \%$, landslides reaches $7 \%$, transport accidents reached $25 \%$ and volcanic eruptions as high as $50 \%$.
\end{abstract}

Key words: Fuzzy Time Series, Markov Chain, Forcasting, Disaster.

\section{Introduction}

Various kinds of natural disasters still occur in Indonesia. The disastrous events make people uneasy and lead to a health crisis. The availability of information on the past is not just a mere documentation, but can be used as a reference for predicting future events.

The concept of Fuzzy Time Series to predict things that will happen based on the data in the past, to learn how the variables change at any time. While the Markov Chain assist in estimating the changes that may occur in the future. Previous research conducted by Ruey-Chyn Tsaur that using fuzzy time series and Markov chain to predict currency of Taiwan with the US dollar (Ruey, 2012).

Using the concept of fuzzy time series and Markov chain, the researchers predicted the occurrence of natural disasters that occur in the future with quantitative forecasting techniques where such techniques use existing data in the past are taken directly from the national disaster management agency. 


\section{Research methods}

The measures undertaken in this study are:

\section{Fuzzy Time Series}

Step - 1 : for the set of the universe $U=\left(D_{\min }, D_{\max }\right)$ be the same number of odd intervals $\left(u_{1}, u_{2}, \ldots . u_{n}\right)$.

Table 1. Table base interval

\begin{tabular}{|c|c|}
\hline Interval & Bases \\
\hline $0.1-1.0$ & 0.1 \\
\hline $1.1-10$ & 1 \\
\hline $11-100$ & 10 \\
\hline $101-1000$ & 100 \\
\hline
\end{tabular}

Step - 2 : Make $\left(A_{1}, A_{2}, \ldots A_{k}\right)$ be a fuzzy set that is where the linguistic determined in accordance with the state of the universe.

$$
\begin{gathered}
A_{1}=k_{11} / u_{1}+k_{12} / u_{2}+\ldots .+k_{1 m} / u_{m} \\
A_{2}=k_{21} / u_{1}+k_{22} / u_{2}+\ldots .+k_{2 m} / u_{m} \\
\cdot \\
\cdot \\
A_{n}=k_{n 1} / u_{1}+k_{n 2} / u_{2}+\ldots .+k_{n m} / u_{m}
\end{gathered}
$$

Step - 3 : Forming fuzzy logical relationship

Step - 4 : Set weight fluctuation

Step - 5 : Calculating the value of linguistic distribution center

Step - 6 : Defuzzification process, with both vectors are multiplied to obtain initial estimates.

$$
\text { Forecast } t_{t+1}=v_{t} w_{t} \quad t=1, \ldots, n
$$

Where :

Forecast $\mathrm{t}+1=$ Forcast to Time $\mathrm{t}+1$

$\mathrm{V}_{\mathrm{t}}=$ vector line $(1 \mathrm{xk})$ to Time $\mathrm{t}$

$W_{t}=$ vector colum $(k \times 1)$ to Time $t$

\section{Markov Chain}

Step - 1 : Create a probability matrix of disasters

$$
\mathrm{P}=\left[\begin{array}{cccc}
p 00 & p 01 & p 02 & . . \\
p 10 & p 11 & p 12 & . . \\
. . & . . & . . & . . \\
p i 0 & p i 1 & p i 2 & . .
\end{array}\right]
$$

Step - 2 : Adjusting the inclination value

$$
\pi(1)=\pi(0) . P
$$

Step - 3 : Determine the results of forecasting 


\section{Results and Discussion}

\section{Description Data}

Data obtained from natural disaster relief agencies are taken in the period from July to September 2015.

Figure -1. Graph Natural Disaster Indonesia 2015

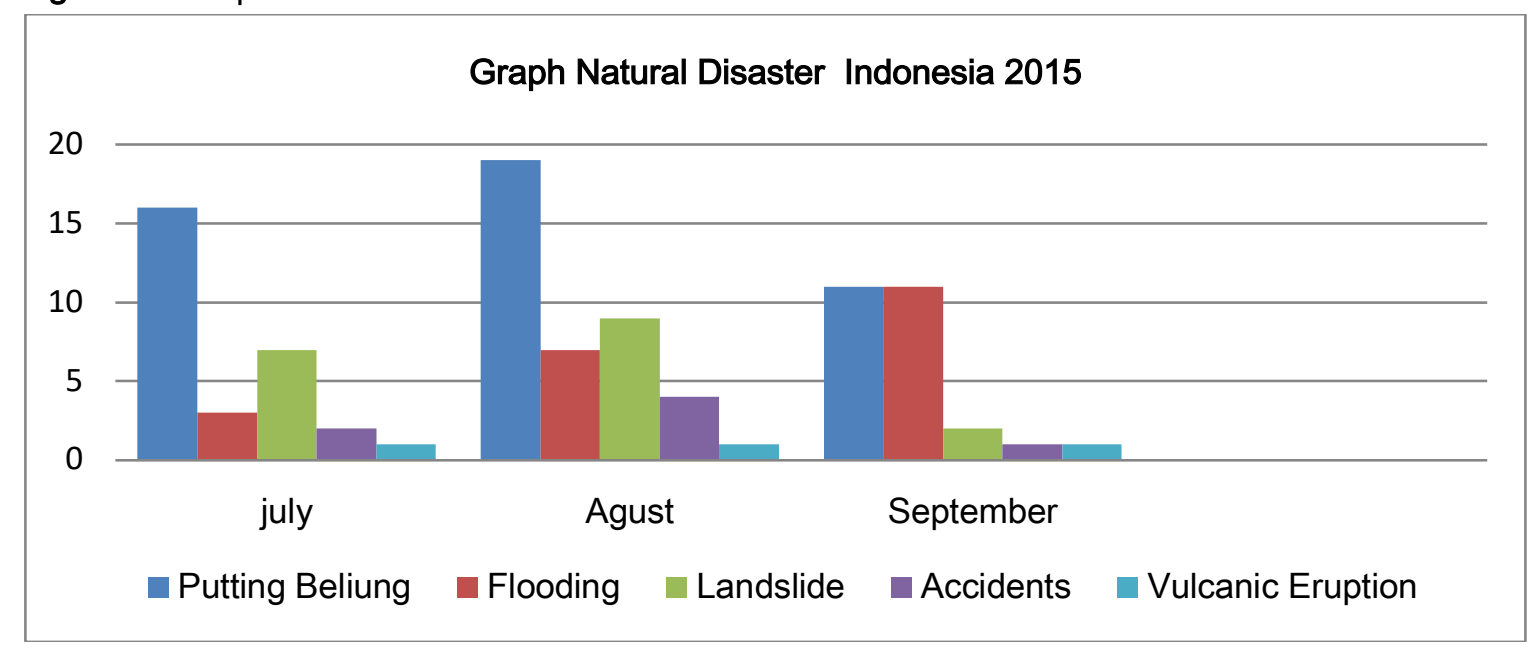

Based on the graph Indonesian natural disasters that occurred from the month of July until September 2015 that as many as 46 events tornado, flood as many as 21 events, landslides total of 18 events, transportation accidents as much as 7 events, and volcanic eruptions as many as three events.

Table 2. Data Disaster in september 2015

\begin{tabular}{|r|l|l|l|l|}
\hline No & \multicolumn{1}{|c|}{ Province } & \multicolumn{1}{|c|}{ District } & \multicolumn{1}{c|}{ Type Disaster } & Date/Year \\
\hline 1 & jawa tengah & pati & puting beliung & $22 / 9 / 2015$ \\
\hline 2 & bangka belitung & bangka & puting beliung & $21 / 9 / 2015$ \\
\hline 3 & jawa timur & situbondo & puting beliung & $21 / 9 / 2015$ \\
\hline 4 & pemerintah aceh & kota subulussalam & banjir & $20 / 9 / 2015$ \\
\hline 5 & jawa barat & sukabumi & tanah longsor & $18 / 9 / 2015$ \\
\hline 6 & sumatera utara & nias barat & banjir & $15 / 9 / 2015$ \\
\hline 7 & jawa timur & pamekasan & puting beliung & $15 / 9 / 2015$ \\
\hline 8 & pemerintah aceh & aceh barat & banjir & $14 / 9 / 2015$ \\
\hline 9 & sumatera utara & simalungun & puting beliung & $14 / 9 / 2015$ \\
\hline 10 & riau & kampar & puting beliung & $14 / 9 / 2015$ \\
\hline 11 & riau & kota pekanbaru & puting beliung & $14 / 9 / 2015$ \\
\hline 12 & pemerintah aceh & aceh barat daya & banjir & $13 / 9 / 2015$ \\
\hline 13 & pemerintah aceh & nagan raya & banjir & $13 / 9 / 2015$ \\
\hline 14 & pemerintah aceh & bener meriah & banjir & $13 / 9 / 2015$ \\
\hline 15 & pemerintah aceh & simeulue & banjir & $12 / 9 / 2015$ \\
\hline 16 & pemerintah aceh & aceh utara & banjir & $12 / 9 / 2015$ \\
\hline
\end{tabular}




\begin{tabular}{|l|l|l|l|l|}
17 & sumatera utara & kota medan & banjir & $12 / 9 / 2015$ \\
\hline 18 & sumatera utara & kota binjai & banjir & $12 / 9 / 2015$ \\
\hline 19 & pemerintah aceh & aceh utara & banjir & $11 / 9 / 2015$ \\
\hline 20 & sumatera utara & serdang bedagai & puting beliung & $11 / 9 / 2015$ \\
\hline 21 & jawa timur & tuban & kecelakaan transportasi & $11 / 9 / 2015$ \\
\hline 22 & jawa timur & bojonegoro & puting beliung & $10 / 9 / 2015$ \\
\hline 23 & kepulauan riau & bintan & puting beliung & $9 / 9 / 2015$ \\
\hline 24 & maluku utara & kota ternate & letusan gunung api & $8 / 9 / 2015$ \\
\hline 25 & jawa barat & kota bogor & tanah longsor & $7 / 9 / 2015$ \\
\hline 26 & kalimantan timur & kota bontang & puting beliung & $5 / 9 / 2015$ \\
\hline
\end{tabular}

\section{Analysis Fuzzy Time Series}

From the data obtained in the specified set of rules $U=\left(D_{\min }, D_{\max }\right)$ be the same number of odd intervals $\left(u_{1}, u_{2}, \ldots . u_{n}\right)$. Where the number of intervals is 7 . From the data obtai ned history $D_{\min }=1, D_{\max }=19$.

7 interval in the universe $U$ is:

$$
\begin{array}{ll}
U_{1}=(11,19) & U_{5}=(1,7) \\
U_{2}=(11,16) & U_{6}=(2,4) \\
U_{3}=(3,7) & U_{7}=(1,2) \\
U_{4}=(2,9) &
\end{array}
$$

Based on the results of the universe $U$ can be determined fuzzy linguistic namely:

$$
\begin{aligned}
& A_{1}=1 / u_{1}+0,5 / u_{2}+0 / u_{3}+0 / u_{4}+0 / u_{5}+0 / u_{6}+0 / u_{7} \\
& A_{2}=0,5 / u_{1}+1 / u_{2}+0,5 / u_{3}+0 / u_{4}+0 / u_{5}+0 / u_{6}+0 / u_{7} \\
& A_{3}=0 / u_{1}+0,5 / u_{2}+1 / u_{3}+0,5 / u_{4}+0 / u_{5}+0 / u_{6}+0 / u_{7} \\
& A_{4}=0,5 / u_{1}+1 / u_{2}+0 / u_{3}+0 / u_{4}+0 / u_{5}+0 / u_{6}+0,5 / u_{7} \\
& A_{5}=0 / u_{1}+0,5 / u_{2}+0 / u_{3}+1 / u_{4}+0 / u_{5}+0 / u_{6}+0 / u_{7} \\
& A_{6}=0 / u_{1}+0 / u_{2}+0 / u_{3}+0,5 / u_{4}+1 / u_{5}+0 / u_{6}+0 / u_{7} \\
& A_{7}=1 / u_{1}+0 / u_{2}+0 / u_{3}+0 / u_{4}+0,5 / u_{5}+0 / u_{6}+1 / u_{7}
\end{aligned}
$$

The next stage of the process is done by natural disasters defuzzification based on data from the month of July to September 2015. Based on the results of the set $U$, the universe can be generated from the data fuzzyfikasi natural disasters which can be seen in the table fuzzyfikasi following: 
Table 3. Table defuzzyfikasi

\begin{tabular}{|c|c|c|c|}
\hline Month & Case & Data & Fuzzyfikasi \\
\hline \multirow{5}{*}{$\stackrel{\varrho}{\varrho}$} & Puting Beliung & 16 & $\mathrm{~A}_{2}$ \\
\hline & Flooding & 3 & $A_{3}$ \\
\hline & Landslide & 7 & $\mathrm{~A}_{3}$ \\
\hline & Accidents Transportation & 2 & $A_{6}$ \\
\hline & Vulcanic Eruption & 1 & $A_{7}$ \\
\hline \multirow{5}{*}{ 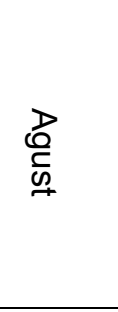 } & Puting Beliung & 19 & $A_{1}$ \\
\hline & Flooding & 7 & $A_{3}$ \\
\hline & Landslide & 9 & $\mathrm{~A}_{4}$ \\
\hline & Accidents Transportation & 4 & $A_{6}$ \\
\hline & Vulcanic Eruption & 1 & $A_{7}$ \\
\hline \multirow{5}{*}{$\begin{array}{l}\mathbb{D} \\
\mathbb{\mathbb { D }} \\
\stackrel{\mathbb{\Phi}}{\mathbb{D}} \\
3 \\
\mathbb{0} \\
\mathbb{\Phi}\end{array}$} & Puting Beliung & 11 & $A_{1}$ \\
\hline & Flooding & 11 & $A_{1}$ \\
\hline & Landslide & 2 & $A_{7}$ \\
\hline & Accidents Transportation & 1 & $\mathrm{~A}_{5}$ \\
\hline & Vulcanic Eruption & 1 & $A_{5}$ \\
\hline
\end{tabular}

For example, the data in July with tornado occurrence is 16 . Because 16 including U2 interval then difuzzyfikasinya to A2.

\section{Markov Chain}

Based on the data table natural disasters can be created matrix as follows:

$P=\left[\begin{array}{lllll}3,2 & 0,6 & 1,4 & 0,4 & 0,2 \\ 3,8 & 1,4 & 1,8 & 0,8 & 0,2 \\ 2,2 & 2,2 & 0,4 & 0,2 & 0,2\end{array}\right]$

$\pi(1)=\pi(0) . P$

$\left[\begin{array}{lllll}1 & 0 & 0 & 0 & 0\end{array}\right] \times\left[\begin{array}{lllll}3,2 & 0,6 & 1,4 & 0,4 & 0,2 \\ 3,8 & 1,4 & 1,8 & 0,8 & 0,2 \\ 2,2 & 2,2 & 0,4 & 0,2 & 0,2\end{array}\right]$

$=\left[\begin{array}{lllll}3,2 & 0,6 & 1,4 & 0,4 & 0,2\end{array}\right]$

For forecasting results in the next year, the tornado reached $3 \%$, reaching $16 \%$ of flood, landslides reaches $7 \%$, reaching $25 \%$ of transportation accidents and volcanic eruptions as high as $50 \%$. 
Figure - 2. Graph the results forecast in the next year

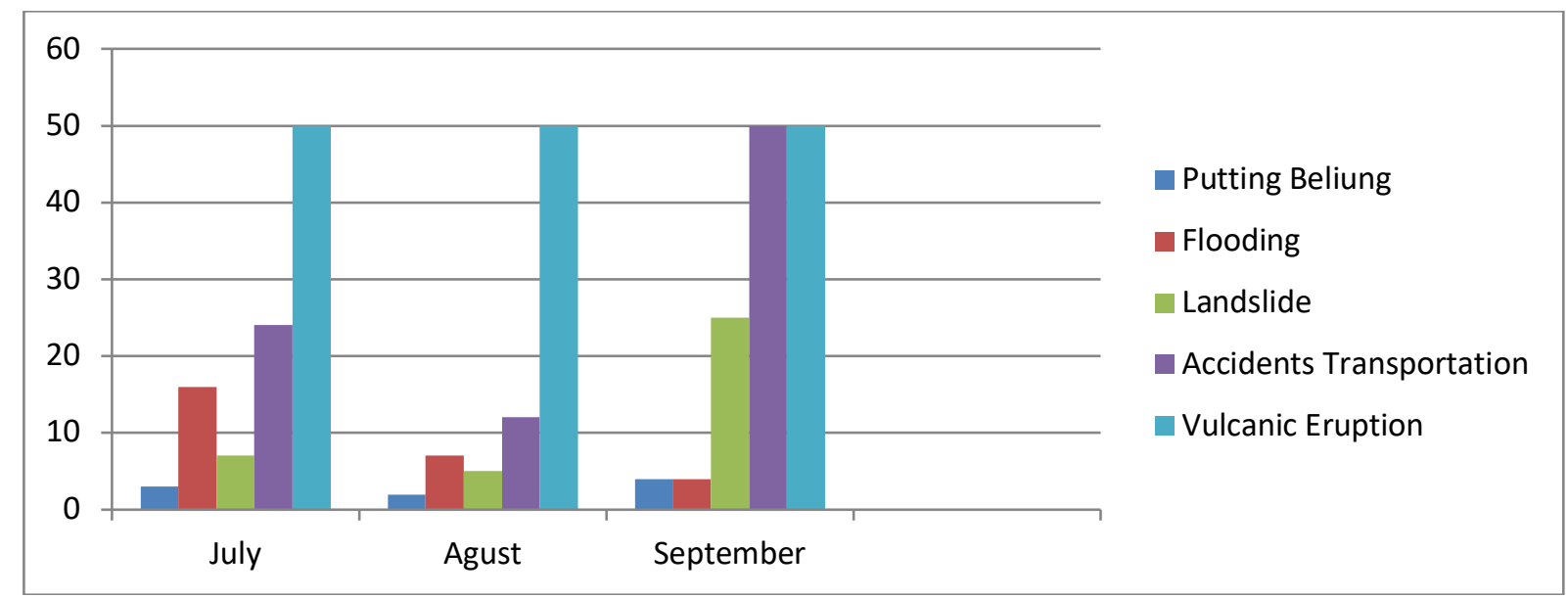

\section{Conclusions}

Based on research that has been done, using fuzzy time series and Markov chain, the prediction of natural disasters following year for tornado reached $3 \%$, floods reaches $16 \%$, landslides reaches $7 \%$, transport accidents reached $25 \%$ and a volcanic eruption reaches $50 \%$, By combining fuzzy time series with Markov chain, better accuracy rate than the usual fuzzy time series.

\section{Acknowledgements}

The advice given by the author is to experiment with larger data using fuzzy time series and Markov chain.

\section{References}

Ruey-Chyn Tsaur. (2012). A fuzzy Time Series-Markov Chain Model With An Application To Forecast The Exchange Rate Between The Taiwan And US Dollar. Vol 8, Number 7(B).

Sasu, Adela. (2010). An Application of Fuzzy Time Series to the Romanian Population. Bulletin of the Transilvania University of Brasov. Vol 3(52) - 2010 Seri ke-3.

Chen, S. M., (1996), Forecasting enrollments based on fuzzy time series-Fuzzy Sets and Systems, International Journal of Applied Science and Engineering, 5, hal. 996-1004.

S. T. Li and Y. C. Cheng, (2007) Deterministic fuzzy time series model for forecasting enrollments, Computers and Mathematics with Applications, vol.53, no.12, pp.1904-1920.

K. Huarng and T. H.-K. Yu, (2006) The application of neural networks to forecast fuzzy time series, Physica $A$, vol.363, no.2, pp.481-491.

V.Vamitha, M.Jeyanthi, S.Rajaram and T.Revathi, (2012). Temperature Prediction Using Fuzzy Time Series and Multivariate Markov Chain, Vol 2, Number 3, pp. 217-230.

Tasha R. Inniss, (2006). Seasonal clustering technique for time series data, Stochastics and Statistics. European Journal of Operational Research, 175,376-384. 
T. L. Chen, C. H. Cheng and H. J. Teoh, (2008), High-order fuzzy time-series based on multiperiod adap-tation model for forecasting stock markets, Physica A, vol.387, no.4, pp.876-888,

Stevenson. (2009). Fuzzy Sets and Fuzzy Logic : Theory and Applications.

Prentice Hall.

Nai - Yi Wang, Shyi - Ming Chen. (2009). Temperature prediction and TAIFEX forecasting based on automatic clustering techniques and two - factors high - order Fuzzy time series.

Expert systems with Applications, 36, 2143 - 2154.

Lee, L.W. Wang, L.H. and Chen, S.M. (2007). Temperature prediction and TAIFEX forecasting based on fuzzy logical relationships and genetic algorithms. Expert Syst. Appl., 33(3), 539-550.

Duru, O., (2010).A fuzzy integrated logical forecasting model for dry bulk shipping index forecasting: An improved fuzzy time series approach. Expert Syst. Appl., 37, 5372-5380. 